\title{
Workloads and burnout of nursing workers
}

\author{
Cargas de trabalho e os desgastes à saúde dos trabalhadores da enfermagem \\ Cargas de trabajo y agotamiento de la salud de los trabajadores de la enfermería
}

\section{Deciane Pintanela de Carvalho' \\ ORCID: 0000-0003-1598-6602 \\ Laurelize Pereira Rocha' \\ ORCID: 0000-0001-9334-6550}

Eliana Cardia de Pinho"

ORCID: 0000-0003-2523-9651

Jamila Geri Tomaschewski-Barlem'

ORCID: 0000-0001-9125-9103

Edison Luiz Devos Barlem'

ORCID: 0000-0001-6239-8657

Leonardo Salomão Goulart'

ORCID: 0000-0002-7587-2474

'Universidade Federal do Rio Grande. Rio Grande, Rio Grande do Sul, Brazil.

"Instituto Federal de Educação, Ciência e Tecnologia do Rio Grande do Sul. Rio Grande, Rio Grande do Sul, Brazil.

How to cite this article:

Carvalho DP, Rocha LP, Pinho EC, Tomaschewski-Barlem JG,

Barlem ELD, Goulart LS. Workloads and burnout of nursing workers. Rev Bras Enferm. 2019;72(6):1435-41. doi: http://dx.doi.org/10.1590/0034-7167-2017-0659

Corresponding Author:

Deciane Pintanela de Carvalho

E-mail: deciane.carvalho@gmail.com

Submission: 08-02-2017 Approval: 04-06-2019

\begin{abstract}
Objective: to identify workloads in nursing work and its association with nursing worker burnout. Method: a cross-sectional study, including 211 nursing workers from a university hospital, between July and August 2016. For the analysis, the descriptive statistics, ChiSquare Test, Fisher's Exact Test and Mann Whitney U-Test were used. Results: the most evidenced loads were biological. A significant association was found between workloads and workers' occupation, as well as a significant association between workloads and worker burnout. Burnout caused upper limb pain, neck and lumbar pain, lower limb pain, muscle spasm, lower limb edema, mental fatigue, headache, nervousness, and forgetfulness. Conclusion: workloads identification is a subsidy for the promotion of interventions that minimize the burnout generated to the health of the nursing worker.

Descriptors: Nursing, Team; Occupational Health; Workload; Burnout, Professional; Nursing.
\end{abstract}

\section{RESUMO}

Objetivo: identificar as cargas de trabalho presentes no trabalho da Enfermagem e a sua associação com os desgastes à saúde dos trabalhadores. Método: estudo transversal, incluindo 211 trabalhadores de enfermagem de um hospital universitário, entre julho e agosto de 2016. Para análise, utilizou-se estatística descritiva e os Testes Qui-Quadrado, Exato de Fisher e Mann Whitney. Resultados: as cargas mais evidenciadas foram as biológicas. Verificou-se associação significativa entre as cargas de trabalho e a função dos trabalhadores, assim como associação significativa entre cargas de trabalho e desgastes à saúde dos trabalhadores. Os desgastes foram dor em membros superiores, dor em região cervical e lombar, dor em membros inferiores, contratura muscular, edema em membros inferiores, cansaço mental, cefaleia, nervosismo e esquecimento. Conclusão: a identificação das cargas de trabalho serve de subsídio para promoção de intervenções que minimizem os desgastes gerados à saúde do trabalhador da Enfermagem.

Descritores: Equipe de Enfermagem; Saúde do Trabalhador; Carga de Trabalho; Esgotamento Profissional; Enfermagem.

\section{RESUMEN}

Objetivo: identificar las cargas de trabajo presentes en el trabajo de la Enfermería y su asociación con los desgastes a la salud de los trabajadores. Método: el estudio transversal, incluyendo 211 trabajadores de enfermería de un hospital universitario, entre julio y agosto de 2016. Para análisis, se utilizó estadística descriptiva y las Pruebas Qui-Cuadrado, Exacto de Fisher y Mann Whitney. Resultados: las cargas más evidenciadas fueron las biológicas. Se verificó una asociación significativa entre las cargas de trabajo y la función de los trabajadores, así como una asociación significativa entre cargas de trabajo y desgastes a la salud de los trabajadores. Los síntomas de agotamiento fueron dolor en miembros superiores, dolor en región cervical y lumbar, dolor en miembros inferiores, contractura muscular, edema en miembros inferiores, cansancio mental, cefalea, nerviosismo y olvido. Conclusión: la identificación de las cargas de trabajo sirve de subsidio para promoción de intervenciones que minimicen los desgastes generados a la salud del trabajador de la Enfermería.

Descriptores: Grupo de Enfermería; Salud Laboral; Carga de Trabajo; Agotamiento Profesional; Enfermería. 


\section{INTRODUCTION}

Work is constituted by conditions that generate workloads that act directly or indirectly in workers' health ${ }^{(1)}$. In nursing, workloads are related to overwork, inadequate physical structures, excessive work hours, and shortages in the quantity of workers. These conditions cause worker burnout, which may present difficulties in the development of patient care ${ }^{(2)}$.

According to the theoretical framework of Laurell and Noriega (1989), workloads are characterized as elements present in the work process. By interacting dynamically with each other and with the worker, they may be responsible for generating new processes of adaptation and, as a consequence, worker burnout, which is defined as loss of the corporal and psychic capacity of workers ${ }^{(3)}$.

Workloads are differentiated by the way they interact in the worker's body. Physical, chemical, biological and mechanical loads are characterized as external materiality loads. They are characterized as inner materiality of physiological and psychic loads ${ }^{(3)}$. Among the external materiality loads, physical loads are the changes in temperature and ionizing radiation; such as chemical loads, the handling of chemicals and medicines in general; the biological loads are identified by exposure to blood, body fluids and handling of contaminated materials ${ }^{(4)}$. Mechanical loads can be characterized by sharps work accidents and physical violence ${ }^{(5)}$.

For internal materiality loads, physiological loads such as carrying out standing work, uncomfortable and inappropriate postures, night work and excessive weight handling are described ${ }^{(5)}$.Psychical loads are related to excessive workload, shortage of workers, accelerated work pace, constant attention, lack of autonomy and communication in the performance of activities ${ }^{(6)}$.

Regarding burnout generated by exposure to nursing workloads, due to physical loads, irritability and neoplasia are identified ${ }^{(7)}$, aspects that may be related to workers' exposure to working environment noise and to ionizing radiations ${ }^{(3)}$. Mechanical loads are responsible for falls, cuts, kinks and fractures. In the face of biological loads, infections of upper and lower limbs. Dermatitis and allergies are evident from chemical loads. For the physiological loads, the main symptoms of burnout are muscle pain and stress. Psychic loads can lead to depression, mood disorder, sadness, anxiety, headache and mental fatigue ${ }^{(7)}$.

Due to the nursing worker burnout, caused by exposure to workloads, it becomes indispensable to identify the loads that the workers are exposed, seeking to prevent and to draw strategies that aim at a healthy work ${ }^{(8)}$. Even if the exposure of nursing workers to workloads seems clear, changes in work processes and improvements in working conditions are hard to achieve realities. This suggests the monitoring of the health of these workers, in order to visualize the reality experienced by them, allowing the identification of workloads involved in the worker's sickness ${ }^{(9-10)}$.

In this sense, this study can contribute to the planning of strategies in hospital environments, from the identification of workloads, by the nursing workers themselves. It allows the discussion of the subject and changes in attitudes and behaviors, with the purpose of modifying the overview evidenced in the literature, on exposure to workloads and burnout. These results seek to promote the implementation of actions with the workers and institutional management, aiming at minimizing the workloads that presented association with worker burnout.

\section{OBJECTIVE}

Identify workloads in nursing work and their association with worker burnout.

\section{METHOD}

\section{Ethical aspects}

The study is part of the macro-project titled "Processo de trabalho e a saúde do trabalhador da enfermagem", which was approved by the Health Research Ethics Committee of the institution, under Opinion 54/2016. It is in accordance with the recommendations of Resolution 446/12 of the Brazilian Health Board (Conselho Nacional de Saúde). Participants signed the Free and Informed Consent Form.

\section{Design, place of study and period}

This is a cross-sectional, quantitative and descriptive study, developed in a University Hospital (UH), in Rio Grande do Sul State. Data collection was performed from July to August 2016.

\section{Population and sample: inclusion and exclusion criteria}

For sample calculation, the population of 355 nursing workers was considered, being 83 nurses, 129 nursing technicians and 143 nursing auxiliaries. The StatCalc program of Epilnfo version 7 and the $95 \%$ confidence level were used. A minimum sample size of 184 participants was obtained. Selection was non-probabilistic, for convenience, in order to understand as many workers as possible. The sample consisted of 211 nursing workers, 49 nurses, 85 nursing technicians and 77 nursing assistants.

Inclusion criteria were: to be a nurse, a nursing technician or a nursing assistant, to be part of the functional unit of the UH for a minimum period of three months and to be active in Emergency Care Units, Risk Classification, General Intensive Care Unit (ICU), Surgical Center, Medical Clinic Unit, Surgical Clinic Unit, Traumatology, Obstetric Inpatient Unit, Obstetric Center, Neonatal ICU, Pediatric Unit, Integrated Diabetes Center, Integrated Regional Center for Diagnosis and Treatment in Gastroenterology, Ambulatory and Materials Center and Sterilization. As criteria for exclusion: acting in administrative positions, withdrawal for health reasons, and license of any nature or vacations at the time of data collection.

\section{Study protocol}

A previously trained team performed data collection. The training took place in meetings scheduled prior to the beginning of the data collection, addressing the subject studied, objectives, questionnaire characteristics, ways of applying the tool, ethical aspects, and identification of possible doubts. Timetables were established for conducting the research, avoiding compromising the study sectors' routines.

Nursing workers were located in the work sectors, in the morning, afternoon and evening shifts, contemplating night I and night II. After clarifying the purpose of the study, they were invited to participate and were guided to complete the questionnaire. 
The questions contained in the questionnaire are open and closed, referring to workers characteristics, such as age, gender (female/male) and occupation (nurse/nursing technician/nursing assistant). The frequency of workloads identified in nursing work was verified by a five-point Likert scale for biological, chemical, mechanical, physical, psychic and physiological loads considering: always $=1$; often $=2$; sometimes $=3$; rarely $=4$; never $=5$.

In order to identify the types of workloads, there were alternative responses (present or absent in the work process) for biological loads (viruses, bacteria, fungi, blood, secretions, excretions, handling of patients with infectious diseases, material handling contaminated); chemical loads (drugs, chemotherapeutic agents, anesthetic gases, dust, antiseptics, sodium hypochlorite, glutaraldehyde, latex gloves); physical loads (noise, temperature difference, humidity, non-ionizing radiation, ionizing radiation); mechanical loads punctures, bruises, fractures, contusions, perforations, cuts, physical violence); psychic loads (monotony, duplicate work, repetitiveness, double shift, overwork, inadequate staffing, lack of autonomy, prolonged tension, work rhythm, speed and precession in the development of activities, pressure of supervision, conflicts, difficult interpersonal relationships between the team); and physiological loads (weight lifting, inadequate posture, uncomfortable and inadequate position, night work, shift work, physical exertion, standing long distances, long distance travel in the institution).

Regarding work-related burnout, the development of pain in upper limbs, cervical region, thoracic region, lumbar, lower limbs, joints, muscle spasm, lower limb edema, shortness of breath, digestive disorders, mental fatigue, headache, nervousness and forgetfulness, insomnia, eye irritation, weakness, and dizziness.

\section{Analysis of results and statistics}

Double typing was used to control data quality in Microsoft Excel. Afterwards, the data were transported to the software Statistical Package for the Social Sciences version 21, to carry out the analysis. Descriptive statistics and the Kolmogorov-Smirnov Test were used to verify the data normality. The Chi-Square Test and Fisher's Exact Test were used to identify the associations between workers' occupation (nurses, nursing technicians and nursing assistants) and types of workloads present in nursing work. The Mann-Whitney U-test was used to analyze the presence of workloads identification between two groups - one presenting group and one group that did not present work-related burnout. $p<0.05$ was adopted as statistical significance.

\section{RESULTS}

The study involved 211 participants. Age ranged from 23 to 68 years, with a median of 41 years. There was a predominance of females, with 188 (89.1\%) participants. Workloads were evidenced as always present in nursing work, considering biological ones, by 152 (72\%) of the participants; psychic loads, by 119 (56.4\%); physiological loads, by 117 (55.5\%); chemical loads, by 112 (53.1\%); physical loads, by 105 (49.8\%); and mechanical loads, by 75 (35.5\%) workers.

Table 1 - Significant statistical associations analysis between workloads present in nursing work and professionals' occupation, Rio Grande, Rio Grande do Sul, Brazil, 2016

\begin{tabular}{|c|c|c|c|c|c|c|c|}
\hline \multirow[t]{2}{*}{ Workload } & \multicolumn{2}{|c|}{ Nurse } & \multicolumn{2}{|c|}{$\begin{array}{l}\text { Occupation } \\
\text { Nurse } \\
\text { Technician }\end{array}$} & \multicolumn{2}{|c|}{$\begin{array}{c}\text { Nursing } \\
\text { Assistant }\end{array}$} & \multirow[t]{2}{*}{$\begin{array}{c}p \\
\text { value }\end{array}$} \\
\hline & $\mathbf{n}$ & $\%$ & n & $\%$ & $\mathbf{n}$ & $\%$ & \\
\hline \multicolumn{8}{|l|}{ Biological load } \\
\hline Virus & & & & & & & $.019^{*}$ \\
\hline Present & 49 & 100 & 80 & 94.1 & 67 & 87 & \\
\hline Absent & 0 & 0 & 5 & 5.59 & 10 & 13 & \\
\hline Bacteria & & & & & & & $.011^{*}$ \\
\hline Present & 49 & 100 & 83 & 97.6 & 69 & 89.6 & \\
\hline Absent & 0 & 0 & 2 & 2.4 & 8 & 10.4 & \\
\hline \multicolumn{8}{|l|}{ Physical load } \\
\hline Humidity & & & & & & & $.001^{*}$ \\
\hline Present & 16 & 32.7 & 26 & 30.6 & 44 & 57.1 & \\
\hline Absent & 33 & 67.3 & 59 & 69.4 & 33 & 42.9 & \\
\hline \multicolumn{8}{|l|}{ Mechanical load } \\
\hline Accidents with sharps & & & & & & & $.029^{*}$ \\
\hline Present & 45 & 91.8 & 74 & 87.1 & 58 & 75.3 & \\
\hline Absent & 4 & 8.2 & 11 & 12.9 & 19 & 24.7 & \\
\hline \multicolumn{8}{|l|}{ Psychic load } \\
\hline Prolonged tension & & & & & & & $.009^{*}$ \\
\hline Present & 38 & 77.6 & 48 & 56.5 & 39 & 50.6 & \\
\hline Absent & 11 & 22.4 & 37 & 43.5 & 38 & 49.4 & \\
\hline Conflicts & & & & & & & $.005^{*}$ \\
\hline Present & 33 & 67.3 & 34 & 40 & 32 & 41.6 & \\
\hline Absent & 16 & 32.7 & 51 & 60 & 45 & 58.4 & \\
\hline Difficult interpersonal relationships among staff & & & & & & & $.047^{* *}$ \\
\hline Present & 24 & 49 & 36 & 42.4 & 22 & 2.6 & \\
\hline Absent & 25 & 51 & 49 & 57.6 & 55 & 71.4 & \\
\hline \multicolumn{8}{|l|}{ Physiological load } \\
\hline Work shift & & & & & & & $.031^{*}$ \\
\hline Present & 4 & 8.2 & 20 & 23.5 & 21 & 27.3 & \\
\hline Absent & 45 & 91.5 & 65 & 76.5 & 56 & 72.7 & \\
\hline Physical effort & & & & & & & $.012^{*}$ \\
\hline Present & 27 & 55.1 & 54 & 63.5 & 61 & 79.2 & \\
\hline Absent & 22 & 44.9 & 31 & 36.5 & 16 & 20.8 & \\
\hline Long distance travel in the institution & & & & & & & $.004^{*}$ \\
\hline Present & 16 & 32.7 & 35 & 41.2 & 47 & 61 & \\
\hline Absent & 33 & 67.3 & 50 & 58.8 & 30 & 39 & \\
\hline
\end{tabular}

Note: *Chi-Square Test; ** Fisher's Exact Test. 
Table 2 - Association between workloads and worker burnout, Rio Grande, Rio Grande do Sul, Brazil, 2016

\begin{tabular}{|c|c|c|c|c|c|c|c|c|c|c|c|c|}
\hline \multirow{3}{*}{ Burnout } & \multicolumn{12}{|c|}{ Workloads } \\
\hline & \multicolumn{2}{|c|}{ Biological } & \multicolumn{2}{|c|}{ Chemical } & \multicolumn{2}{|c|}{ Physical } & \multicolumn{2}{|c|}{ Mechanical } & \multicolumn{2}{|c|}{ Psychic } & \multicolumn{2}{|c|}{ Physiological } \\
\hline & md & $\mathbf{p}$ & md & $\mathbf{P}$ & md & $\mathbf{p}$ & md & $\mathbf{p}$ & md & $\mathbf{p}$ & md & p \\
\hline $\begin{array}{l}\text { Upper limb pain } \\
\qquad \begin{array}{l}\text { Yes }(n=66) \\
\text { No }(n=145)\end{array}\end{array}$ & 1.00 & .132 & 1.00 & $.028^{*}$ & 2.00 & $.004^{*}$ & 2.00 & $.006^{*}$ & 1.00 & .058 & 1.00 & $.007^{*}$ \\
\hline $\begin{array}{l}\text { Cervical region pain } \\
\qquad \begin{array}{l}\text { Yes }(n=106) \\
\text { No }(n=105)\end{array}\end{array}$ & 1.00 & .203 & 1.00 & .054 & 2.00 & $.003^{*}$ & 2.00 & $.000^{*}$ & 1.00 & $.000^{*}$ & 1.00 & $.019^{*}$ \\
\hline $\begin{array}{l}\text { Thoracic region pain } \\
\qquad \begin{array}{l}\text { Yes }(n=22) \\
\text { No }(n=189)\end{array}\end{array}$ & 1.00 & .631 & 1.00 & .351 & 2.00 & .971 & 2.00 & .633 & 1.00 & .362 & 1.00 & .588 \\
\hline $\begin{array}{l}\text { Lumbar pain } \\
\qquad \begin{array}{l}\text { Yes }(n=109) \\
\text { No }(n=102)\end{array}\end{array}$ & 1.00 & .066 & 1.00 & .910 & 2.00 & $.006^{*}$ & 2.00 & $.007^{*}$ & 1.00 & $.007^{*}$ & 1.00 & .085 \\
\hline $\begin{array}{l}\text { Lower limb pain } \\
\qquad \begin{array}{l}\text { Yes }(n=82) \\
\text { No }(n=129)\end{array}\end{array}$ & 1.00 & .299 & 1.00 & .993 & 2.00 & .065 & 2.00 & $.014^{*}$ & 1.00 & .065 & 1.00 & .082 \\
\hline $\begin{array}{l}\text { Joints pain } \\
\qquad \begin{array}{l}\text { Yes }(n=59) \\
\text { No }(n=152)\end{array}\end{array}$ & 1.00 & .912 & 1.00 & .388 & 2.00 & .062 & 2.00 & .142 & 1.00 & .528 & 1.00 & .437 \\
\hline $\begin{array}{l}\text { Muscle spasm } \\
\text { Yes }(n=31) \\
\text { No }(n=180)\end{array}$ & 1.00 & .685 & 1.00 & .970 & 2.00 & .641 & 2.00 & .960 & 1.00 & $.042^{*}$ & 1.00 & .700 \\
\hline $\begin{array}{l}\text { Lower limbs edema } \\
\qquad \begin{array}{l}\text { Yes }(n=59) \\
\text { No }(n=152)\end{array}\end{array}$ & 1.00 & .334 & 1.00 & $.019^{*}$ & 2.00 & .062 & 2.00 & $.020^{*}$ & 1.00 & .126 & 1.00 & .744 \\
\hline $\begin{array}{l}\text { Shortness of breath } \\
\qquad \begin{array}{l}\text { Yes }(n=13) \\
\text { No }(n=198)\end{array}\end{array}$ & 1.00 & .384 & 1.00 & .724 & 2.00 & .482 & 2.00 & .480 & 1.00 & .570 & 1.00 & .058 \\
\hline $\begin{array}{l}\text { Digestive disorders } \\
\qquad \begin{array}{l}\text { Yes }(n=50) \\
\text { No }(n=161)\end{array}\end{array}$ & 1.00 & .257 & 1.00 & .071 & 2.00 & .116 & 2.00 & .074 & 1.00 & .403 & 1.00 & .343 \\
\hline $\begin{array}{c}\text { Mental fatigue } \\
\text { Yes }(n=117) \\
\text { No }(n=94)\end{array}$ & 1.00 & .442 & 1.00 & .154 & 2.00 & .191 & 2.00 & $.002^{*}$ & 1.00 & $.004^{*}$ & 1.00 & .213 \\
\hline $\begin{array}{l}\text { Headache } \\
\qquad \begin{array}{l}\text { Yes }(n=80) \\
\text { No }(n=131)\end{array}\end{array}$ & 1.00 & $.028^{*}$ & 1.00 & $.019^{*}$ & 2.00 & .077 & 2.00 & $.004^{*}$ & 1.00 & $.008^{*}$ & 1.00 & $.024^{*}$ \\
\hline $\begin{array}{l}\text { Nervousness } \\
\qquad \begin{array}{l}\text { Yes }(n=41) \\
\text { No }(n=170)\end{array}\end{array}$ & 1.00 & .349 & 1.00 & .693 & 2.00 & .702 & 2.00 & .159 & 1.00 & $.003^{*}$ & 1.00 & .368 \\
\hline $\begin{array}{l}\text { Forgetfulness } \\
\qquad \begin{array}{l}\text { Yes }(n=65) \\
\text { No }(n=146)\end{array}\end{array}$ & 1.00 & .894 & 1.00 & .289 & 2.00 & .931 & 2.00 & $.046^{*}$ & 1.00 & .745 & 1.00 & .717 \\
\hline $\begin{array}{l}\text { Insomnia } \\
\qquad \begin{array}{l}\text { Yes }(n=93) \\
\text { No }(n=118)\end{array}\end{array}$ & 1.00 & .516 & 1.00 & .561 & 2.00 & .363 & 2.00 & .436 & 1.00 & .498 & 1.00 & .147 \\
\hline $\begin{array}{l}\text { Eye irritation } \\
\qquad \begin{array}{l}\text { Yes }(n=41) \\
\text { No }(n=170)\end{array}\end{array}$ & 1.00 & .546 & 1.00 & .318 & 2.00 & .134 & 2.00 & .136 & 1.00 & .781 & 1.00 & .730 \\
\hline $\begin{array}{l}\text { Weakness } \\
\qquad \begin{array}{l}\text { Yes }(n=18) \\
\text { No }(n=193)\end{array}\end{array}$ & 1.00 & .573 & 1.00 & .690 & 2.00 & .970 & 2.00 & .203 & 1.00 & .628 & 1.00 & .257 \\
\hline $\begin{array}{l}\text { Dizziness } \\
\qquad \begin{array}{l}\text { Yes }(n=27) \\
\text { No }(n=184)\end{array}\end{array}$ & 1.00 & .746 & 1.00 & .416 & 2.00 & .318 & 2.00 & .107 & 1.00 & .505 & 1.00 & .313 \\
\hline
\end{tabular}

Note: *Chi-Square Test; ** Fisher's Exact Test.
There was a statistically significant association between workloads and the role of nursing workers. Biological loads, which presented statistical significance, were viruses $(p=0.019)$ and bacteria $(p=0.011)$. As for physical loads, humidity ( $p=0.001)$. In mechanical loads, accidents with sharps $(p=0.029)$. In psychic loads, prolonged tension ( $p=0.009)$, conflicts $(p=0.005)$ and difficult interpersonal relationships between the team $(p=0.047)$. In relation to physiological loads, shift work $(p=0.031)$, physical effort $(p=0.012)$ and long distance travel in the institution $(p=0.004)$ (Table 1). Other biological, physical, mechanical, psychic, and physiological workloads were tested. Nevertheless, they did not present significant statistical associations, nor did any type of chemical load.

For the association between workrelated burnout and workloads, the Mann-Whitney U-Test was used. It showed a significant association between work-related health and biological (median=1.00, $p=0.033$ ), mechanical (median $=2.00, p=0.042$ ), psychic (median $=1.00 ; \mathrm{p}=0.002$ ) and physical loads (median $=2.00, p=0.003$ ).

In Table 2, only the statistically significant association between the types of workload and burnout. There was an association between burnout and upper limb pain with chemical $(p=0.028)$, physical $(p=0.004)$, mechanical $(p=0.006)$ and physiological load ( $p=0.007)$; burnout and cervical region pain with physical $(p=0.003)$, mechanical $(p=0.000)$, psychic $(p=0.000)$ and physiological load $(p=0.019)$; between lower limb pain and physical load ( $p=0.006)$, mechanical $(p=0.007)$ and psychic $(p=0.007)$; lower limbs pain with mechanical load ( $p=0.014)$; between muscular spasm and psychic load ( $p=0.042$ ); edema in lower limbs with chemical load $(p=0.019)$ and mechanical load ( $p=0.020)$;burnout mental fatigue with mechanical load $(p=0.002)$ and psychic (0.004); headache with biological $(p=0.028)$, chemical $(p=0.019)$, mechanical $(p=0.004)$, psychic $(p=0.008)$ and physiological load $(p=0.024)$; between nervousness and psychic load (0.003) and forgetfulness with mechanical load $(p=0.046)$. 


\section{DISCUSSION}

According to the results, $72 \%$ of nursing workers identified the biological loads as always present at work. This result may be related to the very characteristic of nursing work, which involves direct contact with patients, exposing workers to infectious diseases, body fluids, blood and secretions, during the performance of procedures. In addition, contaminated material handling, through the use of sharps, such as needles, during and after nursing care, is highlighted ${ }^{(11)}$.

There was a significant association between workloads and workers' occupation. The biological loads that presented a significant association were viruses and bacteria, and nurses were the professional category that most identified the presence of these types of loads in the work environment, which can portray that nursing workers identify these loads as potential for the development of viral and bacterial infections. The most frequent burnout symptoms among hospital workers, especially nursing workers, are related to exposure to biological loads, among them, respiratory diseases, conjunctivitis and gastrointestinal infections ${ }^{(10)}$.

Corroborating with these data, a study ${ }^{(12)}$ with nursing workers identified that among the reports of diseases of the respiratory system, influences, airway infections, tonsillitis and acute sinusitis are mentioned. Infectious and parasitic diseases include infectious diarrhea and gastroenteritis. Nonetheless, the most affected professional category was nursing technicians, followed by nursing assistants.

As physical loads, moisture was evidenced with a significant association. Nursing assistants are the workers who identify the most at work. This was highlighted by $22 \%$ of health workers, including nurses and nursing technicians, who work in hospital operating wards in Iran, identifying humidity as an ever-present factor and a potential source of stress in the work environment ${ }^{(13)}$.

Among the mechanical loads, sharps injuries had a significant association with workers' occupation. The nurses were the ones who most evidenced the presence of these loads. This association may be related to the activities developed by the nursing team, which involves the manipulation of these materials, which can cause accidents. This characteristic is evidenced in a study ${ }^{(14)}$ with 69 records of work accidents with nursing workers, $68.1 \%$ of them with nursing auxiliaries, $20.3 \%$ with nurses and $11.6 \%$ among nursing technicians. Among the activities developed at the time of sharps accident, venous puncture (35.71\%), material discarding (21.42\%) and material washing (9.55\%) were the most noteworthy.

As for the psychic loads, there was a significant association between prolonged tension, conflicts and difficult interpersonal relations between the team, which can occur both in relation to worker and patient, and between worker and work team. Nurses frequently identified their presence. Corroborating with these findings, psychic loads in nursing work are characterized by the existence of tension situations during the activities, followed by permanent care and fast pace of work, as well as the difficulty in exercising the autonomy and requirement of the work supervision ${ }^{(15)}$.

Furthermore, physiological loads, such as physical effort, shift work and long distance travel in the institution had a significant association with occupation. Nursing assistants were the professional category that most frequently identified their presence in the work environment. Among the physiological loads evidenced in nursing work, are the distances covered, work in the standing position during most of the period, requirement of physical effort, work shift and night, among others that may be responsible for the presence of tiredness and illness of workers ${ }^{(5)}$.

Nursing work is characterized by the exposure of workers to different workloads, which generate physical and mental fatigue ${ }^{(16)}$. In this study, there was a statistically significant association between wear of nursing workers and biological, mechanical, psychic, and physical loads.

Biological loads were associated with headache, which may occur due to other diseases resulting from viral or bacterial infections, characterizing exposure to biological loads. According to these findings, headache was evidenced by 162 nursing workers, who work in a hospital in the Northwest region of Rio Grande do Sul State, Brazil, as related to allergic rhinitis, respiratory diseases, sinusitis and gastrointestinal disorders ${ }^{(17)}$.

Chemical loads were statistically associated with upper limb wear and pain, lower limb edema and headache, which may be related to drug handling and contact with chemicals during the preparation of medications, which is common in nursing practice. Antineoplastic chemotherapeutics handling for cancer treatment is among the examples of occupational exposure of nursing workers that can cause health damage and be identified by signs and symptoms such as headache, nausea, throat irritation and heat on the face ${ }^{(18)}$.

Burnout symptoms, which were associated with physical loads, were pain in upper limbs, in the cervical region, lumbar region and may be related to irritability ${ }^{(7)}$. Situations of irritability and stress were observed among nursing workers and associated with musculoskeletal injuries, especially in the neck, shoulders, back and waist regions ${ }^{(19)}$.

Findings evidenced several significant associations with mechanical loads, among them pain in upper limbs, cervical region, lumbar and lower limbs, lower limb edema, mental fatigue, headache and forgetfulness. Burnout symptoms related to mechanical loads can occur due to work accidents such as sprains, fractures, displacements, contusions, which cause musculoskeletal pain ${ }^{(8)}$. Similarly, cervical spine problems and disc herniation are causes of tension headache among nursing workers ${ }^{(17)}$.

Psychic loads had a significant association with pain in the cervical and lumbar region, muscular contracture, mental fatigue, headache and nervousness. These results are similar to the findings of a study ${ }^{(6)}$ that identified that psychic loads generate physical and mental fatigue in nursing workers, evidencing increased fatigue, irritability, difficulty concentrating, sleep disturbances and fear of committing mistakes.

Physiological loads indicated an association with upper limb pain, neck pain and headache. Burnout is also evidenced in other studies ${ }^{(10)}$, with nursing workers who have shown that physiological loads can cause headache, shoulder and joint pain, disc herniation, lumbar pain, tendonitis in the arm and shoulder, among others.

\section{Study limitations}

The limitations of the study are related to the cross-sectional design and this study development in a single workplace, which 
does not allow the generalization of results among nursing workers. However, results demonstrate the need to evaluate these workers in other work environments, due to the identification of the significant association of work-related burnout with workloads.

\section{Contributions to Nursing, Health or Public Policy}

The results obtained contribute to Nursing, Health or Public Policy, as they enable the search for interventions that avoid nursing worker burnout, as well as actions that minimize exposure to workloads. It is suggested that new studies be carried out to identify workloads and their association with nursing worker burnout, in other realities, making it possible to compare the results.

\section{CONCLUSION}

Workloads, as always present in the nursing work, were biological loads, followed by psychic, physiological, chemical, physical and mechanical loads. Workloads had a significant association with the role of nursing workers and health-related work-related injuries. Burnout symptoms, with the greatest number of significant associations with exposure to workloads, were upper limb pain, cervical pain and headache, followed by lower limb pain.

Workloads identification can subsidize promotion actions that minimize the burnout generated to the health of the worker, since many workers become ill because of conflicts and difficult interpersonal relationships among the team. Services management should be responsible for organizing and planning adequate physical structure, the number of workers sufficient for the development of activities, seeking to prevent workers from traveling long distances in the institutions and carrying out excessive physical effort.

These results make possible the discussion on the theme, with a view to raising the awareness of nursing workers, managers and academics linked to the institution. In this way, strategies must be implemented to change attitudes and behaviors, with the purpose of modifying the overview evidenced, since it highlights situations that require immediate intervention and influence the accomplishment of a quality assistance.

\section{REFERENCES}

1. Rocha LP, Cezar-Vaz MR, Almeida MCV, Borges AM, Silva MS, Sena-Castanheira J. Workloads and occupational accidents in a rural environment. Texto Contexto Enferm. 2015;24(2):325-35. doi: http://dx.doi.org/10.1590/0104-07072015000480014

2. Pires DEP, Machado RR, Soratto J, Scherer MA, Gonçalves ASR, Trindade LL. Nursing workloads in family health: implications for universal access. Rev Latino-Am Enfermagem. 2016;24:e2677. doi: http://dx.doi.org/10.1590/1518-8345.0992.2682

3. Laurell AC, Noriega M. Processo de produção e saúde: trabalho e desgaste operário. São Paulo: Hucitec; 1989.

4. Flôr RC, Gelbcke FL. Analysis of workloads due to the praxis of nursing aiming the hemodynamic service. J Nurs UFPE. 2013;7(Esp):7034-41. doi: 10.5205/reuol.4767-42136-1-ED.0712esp201310

5. Felli VEA. Condições de trabalho de enfermagem e adoecimento: motivos para a redução da jornada de trabalho para 30 horas. Enferm Foco. 2012;3(4):178-81. doi: https://doi.org/10.21675/2357-707X.2012.v3.n4.379

6. Ferreira MM, Ferreira C. Carga mental e carga psíquica em profissionais de enfermagem. RPESM [Internet]. 2014 [cited 2017 Jul 13];ESP1:4752. Available from: https://issuu.com/spesm/docs/revista_especial_1

7. Silva SM, Baptista PCP, Felli VEA, Martins AC, Sarquis LMM, Mininel VA. Intervention strategies for the health of university hospital nursing staff in Brazil. Rev Latino-Am Enfermagem. 2013;21(1):300-8. doi: 10.1590/S0104-11692013000100003

8. Karino ME, Felli VEA, Sarquis LMM, Santana LL, Silva SR, Teixeira RC. Workloads and strain processes of nursing workers at teaching hospital. Cienc Cuid Saude. 2015;14(2):1011-8. doi: http://dx.doi.org/10.4025/cienccuidsaude.v14i2.21603

9. Felli VEA, Costa TF, Baptista PCP, Guimarães ALO, Anginoni BM. Exposure of nursing workers to workloads and their consequences. Rev EsC Enferm USP. 2015;49(Esp2):96-103. doi: 10.1590/S0080-623420150000800014.

10. Santana LL, Sarquis LMM, Miranda FMD, Kalinke LP, Felli VEA, Mininel VA. Health indicators of workers of the hospital area. Rev Bras Enferm [Internet]. 2016;69(1):23-32. doi: http://dx.doi.org/10.1590/0034-7167.2016690104i

11. Sarquis LMM, Baptista PCP, Mininel VA, Silva FJ, Felli VEA. Exposure to biological material: consequences for nursing professionals. Cienc Cuid Saude. 2013;12(4):697-703. doi: 10.4025/cienccuidsaude.v12i4.14742

12. Guimarães ALO, Felli VEA. Notification of health problems among nursing workers in university hospitals. Rev Bras Enferm [Internet]. 2016;69(3):475-82. doi: http://dx.doi.org/10.1590/0034-7167.2016690313i

13. Azizpour Y, Shohani M, Sayehmiri K, Kikhavani S. A survey on the associated factors of stress among operating room personnel. Thrita. 2013;2(3):19-23. doi: 10.5812/thrita.9505

14. Marziale MHP, Santos HEC, Trovó MEM. Consequências individuais e ocupacionais da exposição a material biológico entre trabalhadores de enfermagem. Rev Enferm UERJ. 2015;23(4):449-54. doi: http://dx.doi.org/10.12957/reuerj.2015.9481

15. Kirchhof ALC, Lacerda MR, Sarquis LMM, Magnago TSB, Gomes IM. Compreendendo cargas de trabalho na pesquisa em saúde ocupacional na enfermagem. Colomb Med. [Internet]. 2011 [cited 2017 Jul 13];42(Supl1):113-9. Available from: http://www.scielo.org.co/pdf/cm/ v42n2s1/v42n2s1a14.pdf 
16. Felli VEA, Baptista PCP, Mininel VA, Sarquis LMM. Indicators to surveillance the health of nursing staff. Occup Environ Med. 2013;70(Suppl 1):A52. doi: http://dx.doi.org/10.1136/oemed-2013-101717.155

17. Moraes EM, Maciel LD, Fontana RT. La cefalea y la salud del trabajador de enfermería: análisis de una realidade. Enferm Global [Internet]. 2012 [cited 2017 Jul 13];11(2):117-25. Available from: http://revistas.um.es/eglobal/article/view/138731/133411

18. Senna MH, Silva CC, Gelbcke FL, Anders JC, Mesquita MPL. A segurança do trabalhador de enfermagem na administração de quimioterápicos antineoplásicos por via endovenosa. Rev Enferm UERJ. 2014;22(5):649-55. doi: http://dx.doi.org/10.12957/ reuerj.2014.15513

19. Azma K, Hosseini A, Safarian MH, Abedi M. Evaluation of the Relationship Between Musculoskeletal Discomforts and Occupational Stressors Among Nurses. N Am J Med Sci. 2015;7(7): 322-7. doi: 10.4103/1947-2714.161250 